\title{
Impact study of Influence of Agricultural Mass Media Programme on Farmers
}

\author{
Deepa Indoria ${ }^{1 *}$, Mani Ram ${ }^{2}$ and R.L. Solanki ${ }^{1}$ \\ ${ }^{1}$ KVK, Chittorgarh, MPUAT, Udaipur, Rajasthan, India \\ ${ }^{2}$ KVK, Rajasamand, MPUAT, Udaipur, Rajasthan, India \\ *Corresponding author
}

\section{Keywords \\ Mass Media, Telecast, Broadcasting, Recording, Editing, Publication \\ Article Info \\ Accepted: \\ 18 August 2018 Available Online: 10 September 2018}

\section{A B S T R A C T}

The present study was conducted in Chittorgarh region of Rajasthan. Out of five districts in Chittorgarh region, two districts Chittorgarh and Pratapgarh were selected randomly by using simple random sampling. From the selected two districts, a total of 6 panchayat samities were selected randomly. A total 29 villages were selected randomly from the selected panchayat samities in proportion to size of the panchayat samities. From each selected village 10 per cent respondents were selected. In this way a total of 302 respondents were selected for study purpose. Majority (92.72 per cent) of farmers were aware about the name of 'Kheti Ri Batan' programme broadcasted by AIR, Chittorgarh. More than two-third of the respondents were using radio for the timings of broadcast of the 'Kheti Ri Batan' programme of AIR, Chittorgarh. Majority ( 85.43 per cent) of the respondents were aware about, the duration of broadcast of 'Krasha Ri Batan'. All the respondents were aware about the name of the farm TV programme, like 'Rajasthani news', 'Rangoli' and entertainment programmes followed by more than 90 per cent of farmers were aware about the name of 'Choupal', 'Krishi Darshan', 'Kalyani', 'Kheti Badi', 'Prashnottri' programmes delivered from Doordharshan Kendra Chittorgarh. All the respondents were aware about the duration of telecast of Rangoli, film and entertainment programmes followed by more than 90 per cent farmers who were aware about the duration of telecast of 'Choupal' and 'Kheti Badi', programmes. Majority (61.92 percent, 57.62 per cent and 48.34 per cent) of respondents were aware about the name of farm magazines viz. 'Khet Khaliyan', 'Kheti Ri Batan' and 'Chokhi Kheti', respectively. Majority of respondents ( 85.76 per cent and 83.11 per cent) were aware about the name of newspapers like 'Dainik Bhaskar' and 'Rajasthan Patrika', respectively.

\section{Introduction}

The first and the foremost act of human being in this world are to communicate. The first cry of the newly born child is meant to communicate to the world that he is born alive and well. Since birth every living moment of his/her consists of a series of learning through communication by cries, symbols, gestures and language. Communication is the mechanism through which human relations exist and develop. In India, Radio is one of most important components of mass media, which became an integral part of the human life and society since ages. Because of its quick coverage, wide reach and popularly, 
radio is considered as an efficiency and ideal tool for talking a wide variety of subjects to the public. Even in agriculture sector, the role of radio is instrumental especially in disseminating the agricultural information to the farmers quickly and in time. In a big country like India where agriculture is the primary activity for majority of the rural population and where the farmers are largely illiterates and confined to the remote villages, radio could play key role not only in quick spreading of farming information but also to broaden the knowledge base of the farmers.

Thus, radio is not only a powerful media of mass communication which speedily disseminates agricultural information but also help to bridge the gap between scientists and farmers. Considering these merits, farm broadcasts have received much attention after the initiation of "Farm and Home" units in all India Radio, during 1967. Television is also considered very strongly as the first stage of awareness. Apart from that, it speeds up entire process of adoption. It is considered as a credible source of information and is taken as authentic, trustworthy and prestigious form of communication.

Television as an audio-visual medium of communication offers immense potential for penetrating technological information to remote corners of the country, through the nationwide T.V. network. The printed word has a long lasting impact on the readers as it can be referred again and again but even after 50 years of independence, Indian press has given only a precarious coverage to agricultural news (Annual report 2007). The increasing level of literacy in the rural areas offers new promises and prospects for the development of farm journalism. The utilization of the print media is bound to increase manifold. Looking to the importance of these media the present study was undertaken.

\section{Materials and Methods}

The present study was conducted in Chittorgarh region of Rajasthan, which had AIR station, Doordharshan Kendra, publication regional head. Out of five districts in Chittorgarh region, two districts Chittorgarh and Pratapgarh were selected randomly by using simple random sampling technique. From the selected two districts, 30 per cent panchayat samities i.e. 4 panchayat samities from Chittorgarh and 2 panchayat samities from Pratapgarh and a total of 6 panchayat samities were selected randomly. A total 29 villages were selected randomly from the selected panchayat samities in proportion to size of the panchayat samities. From each selected village 10 per cent respondents were selected randomly in proportion to the size of the selected villages. In this way a total of 302 respondents were selected for study purpose. The investigator collected data by using a pretested structured schedule employing personal interview technique. Thereafter, the data were classified, tabulated, statistically analysed and interpreted in light of the objective of the study, which led to following findings.

\section{Results and Discussion}

Awareness of name, time and duration of farm radio programmes

It was considered important to study the awareness of name, time and duration of different farm radio programmes of AIR, Chittorgarh with the motive to know the popularity of these programmes among the farmers.

Awareness of name of farm radio programmes

The data presented in the Table 1 reveal that 92.27 per cent farmers were aware about the 
radio programme "Kheti Ri Batan" followed by 92.05 per cent, 86.75 per cent, 85.76 per cent and 80.79 per cent of respondents were aware of the name of 'Krasha Ri Batan', 'Gram Deep', 'Krishi Lok' and 'Panihari' programme of AIR, Chittorgarh respectively. Only 76.16 per cent farmers were aware of the farm radio programe 'Gram Bharti'. It shows that majority of the respondents were aware about the name of evening chunk rural programmes on radio. It might be due to the fact that the evening rural programmes are the oldest and farmers get free time to listen these programmes during evening hours.

Shareef-Ud-Din (1994) reported that majority of the farmers were aware about the name of farm radio programmes of Kashmir radio. Narahari (2001) and Saravanan et al., (2009) reported similar findings.

\section{Time of broadcast of the radio programmes}

The data in Table 1 show that more than twothird of whole respondents using radio were aware about the timings of broadcast of the 'Kheti Ri Batan' (81.46 per cent), Krasha Ri Batan' (80.13 per cent), 'Gram Deep' (77.15 per cent), 'Krishi Lok' (84.11 per cent), 'Panihari' (69.54 per cent), and 'Gram Bharti' (71.52 per cent) farm radio programmes of AIR, Chittorgarh and Shareef-Ud-Din (1994) reported similar results.

\section{Duration of broadcasts of farm radio programmes}

The data presented in Table 1 reveal that majority (85.43 per cent) of the respondent were aware about the duration of broadcast of 'Krasha ri Batan', whereas 82.78 per cent respondents were aware about the duration of 'Kheti Ri Batan' followed by near about threefourth of the respondents who were aware about the duration of 'Gram Deep' (74.17 per cent), 'Krishi Lok' (75.17 per cent), 'Panihari'
(77.81 per cent), and 'Gram Bharti' (72.19 per cent) programmes of AIR, Chittorgarh. These findings indicate that larger number of farmers were aware about the duration of broadcasts of evening and noon chunck programmes, which are more than the morning broadcasts. Shareef-Ud-Din (1994), Narahari (2001), Praveena and Ramiah (2007) and Slathia et al., (2011) reported similar results. Further, the calculated value of chi-square (4.32) is less than the tabulated value of chi- square (18.30) at 10 degrees of freedom at 5 per cent level of significance. It means that there is a no significant agreement between the farmers awareness about the name, time and duration of radio programmes. Hence it can be concluded that the farmers under study differ in their awareness of name, time and duration of radio programmes.

\section{Awareness of name, time of telecast and duration of farm television programmes}

Like farm radio programmes it was also felt important to study the awareness of name, time and duration of telecast of TV programmes of Doordarshan Kendra, Chittorgarh with the motive to know the popularity of these programmes among the TV viewing farmers.

\section{Awareness of name of the television programmes}

The data presented in Table 2 reveal that all the respondents (100.00 per cent) were aware about the name of 'Rajasthani news', 'Rangoli' and entertainment programmes followed by more than 90 percent aware of about the name of 'Choupal' (96.69 per cent), 'Krishi Darshan' (96.36 per cent), 'Kalyani' (91.39 per cent), 'Kheti Badi' (92.72 per cent), 'Prashnottri' (97.35 per cent) programmes delivered from Doordarshan Kendra, Chittorgarh, respectively and only 72.85 per cent respondents were aware about the name of 
'Srijjan' programme. These findings indicate that larger number of farmers was aware about the evening and noon chunk programmes, the durations of which are more than the morning telecast. Laharia and Joshi (1992), Chahal (1992) Praveena and Ramiah (2007) and Slathia et al., (2011) reported similar results.

Awareness of time of telecast of the television programme

The data presented in Table 2 indicate that all the respondents were aware about the time of telecast of Rangoli, film and entertainment programmes followed by more than 90 per cent were aware about the time of telecast of 'Rajasthani News' (91.06 per cent), 'Choupal' (93.05 per cent), 'Krishi Darshan' (90.06 per cent), and more than 80 per cent were aware about the time of telecast of 'Kalyani' (87.75 per cent), 'Kheti Badi' (89.74 per cent), 'Prashnottri' (80.13 per cent), respectively which are delivered from Doordarshan Kendra, Chittorgarh. Whereas, only 60.26 per cent respondents were aware about the time of telecast of 'Srijjan' programme of Doordarshan Kendra, Chittorgarh. The findings of Sodhi and Sangha (1992) and Chahal (1992) also corroborate this findings.

Table.1 Farmer's awareness about name, time of telecast and duration of television programmes $\mathrm{n}=302$ (Multiple response)

\begin{tabular}{|c|c|c|c|c|c|c|c|c|c|c|c|c|}
\hline \multirow[t]{2}{*}{ Programme } & \multicolumn{4}{|c|}{ Name of programme } & \multicolumn{4}{|c|}{ Time of Programme } & \multicolumn{4}{|c|}{ Duration of Programme } \\
\hline & Aware & $\%$ & $\begin{array}{c}\text { Un- } \\
\text { aware }\end{array}$ & $\%$ & Aware & $\%$ & $\begin{array}{c}\text { Un- } \\
\text { aware }\end{array}$ & $\%$ & Aware & $\%$ & $\begin{array}{c}\text { Un- } \\
\text { aware }\end{array}$ & $\%$ \\
\hline Rajasthani News & 302 & 100.00 & 0 & 0.00 & 275 & 91.06 & 27 & 8.94 & 263 & 87.08 & 39 & 12.92 \\
\hline Choupal & 292 & 96.69 & 10 & 3.31 & 281 & 93.05 & 21 & 6.95 & 286 & 94.70 & 16 & 5.30 \\
\hline Krishi Darshan & 291 & 96.36 & 11 & 3.64 & 272 & 90.06 & 30 & 9.94 & 267 & 88.41 & 35 & 11.59 \\
\hline Kalyani & 276 & 91.39 & 26 & 8.61 & 265 & 87.75 & 37 & 12.25 & 255 & 84.44 & 47 & 15.56 \\
\hline Kheti Badi & 280 & 92.72 & 22 & 7.28 & 271 & 89.74 & 31 & 10.26 & 276 & 91.39 & 26 & 8.61 \\
\hline Prashnottari & 294 & 97.35 & 8 & 2.65 & 242 & 80.13 & 60 & 19.87 & 242 & 80.13 & 60 & 19.87 \\
\hline Srijjan & 220 & 72.85 & 82 & 27.15 & 182 & 60.26 & 120 & 39.74 & 207 & 68.54 & 95 & 31.46 \\
\hline Rangoli/ Film & 302 & 100.00 & 0 & 0.00 & 302 & 100.00 & 0 & 0.00 & 302 & 100.00 & 0 & 0.00 \\
\hline
\end{tabular}

$\mathrm{X}^{2}=7.49 \mathrm{NS}$ (Tabulated value at 0.05 level of probability $=23.7$ ) d.f. $=14, \mathrm{NS}=$ Non significant, $\%=$ percentage $\%$ percentage

Table.2 Farmer's awareness about the name of farm magazines

$\mathrm{n}=302$ (Multiple response)

\begin{tabular}{|c|c|c|c|c|c|c|}
\hline S. & Name of Magazines & \multicolumn{3}{|c|}{ Aware } & \multicolumn{2}{|c|}{ Unaware } \\
\hline No. & & \multicolumn{2}{|c|}{ F } & $\%$ & F & $\%$ \\
\hline 1. & Khet Khaliyan & \multicolumn{2}{|c|}{187} & 61.92 & 115 & 38.08 \\
\hline 2. & Kheti Ri Batan & 174 & 57.62 & 128 & 42.38 \\
\hline 3. & Chokhi Kheti & 146 & 48.34 & 156 & 51.66 \\
\hline 4. & Unnat Krishi & 127 & 42.05 & 175 & 57.95 \\
\hline 5. & Fal Sabji & 87 & 28.81 & 215 & 71.19 \\
\hline
\end{tabular}

$\mathrm{X}^{2}=83.50^{* * *}$ (Tabulated value at 0.01 level of probability (13.3) d.f. $=4, * *=$ Significant at 1 per cent level of significance, $\mathrm{F}=$ Frequency $\%$ = percentage 
Table.3 Farmer's awareness about the name of newspapers

\begin{tabular}{|c|c|c|c|c|c|}
\hline \multirow{2}{*}{$\begin{array}{l}\text { S. } \\
\text { No } \\
\end{array}$} & \multirow{2}{*}{$\begin{array}{c}\text { Name of } \\
\text { Newspapers }\end{array}$} & \multicolumn{2}{|c|}{ Aware } & \multicolumn{2}{|c|}{ Unaware } \\
\hline & & $\mathrm{F}$ & $\%$ & $\mathrm{~F}$ & $\%$ \\
\hline 1 & Dainik Bhaskar & 259 & 85.76 & 43 & 14.24 \\
\hline 2 & Rajasthan Patrika & 251 & 83.11 & 51 & 16.89 \\
\hline 3 & Dainik Jagaran & 161 & 53.31 & 141 & 46.69 \\
\hline 4 & Danik Navjyoti & 178 & 58.94 & 124 & 41.06 \\
\hline 5 & Rajasthan Kesari & 134 & 44.37 & 168 & 55.63 \\
\hline
\end{tabular}

\section{Awareness of the duration of telecast of television programmes}

The data presented in Table 2 indicate that all the respondents ( 100.00 per cent) were aware about the duration of telecast of Rangoli, film and entertainment programmes followed by more than 90 per cent farmers were aware about the duration of telecast of 'Choupal' (94.70 per cent) and 'Kheti Badi' (91.39 per cent), more than 80 percent were aware about the duration of telecast of 'Rajasthani News' (87.08 per cent) 'Kalyani' (84.44 per cent), 'Krishi Darshan' (88.41 per cent) and 'Prashnottri' (80.13 per cent) programmes delivered from Doordarshan Kendra, Chittorgarh. Whereas 68.54 per cent respondents were aware about the duration of telecast of 'Srijjan' programme of Doordarshan Kendra, Chittorgarh.

The findings of Sodhi and Sangha (1992) and Chahal (1992) also corroborate this fact.

Further, the calculated value of chi-square (7.49) is less than the tabulated value of chisquare (23.70) at 14 degrees of freedom at 5 per cent level of significance. It means that there is a no significant agreement between the farmers' awareness of name, time and duration of different television programmes. Hence, it can be concluded that the farmers under study differ in their awareness of name, time and duration of television programmes.

\section{Awareness about name of farm magazines}

The data presented in the Table 3 reveal that 61.92 per cent farmers were aware about the name of farm magazine 'Khet Khaliyan', followed by 57.62 per cent, 48.34 per cent and 42.05 per cent of respondents were aware about the name of farm magazines viz. 'Kheti Ri Batan', 'Chokhi Kheti' and 'Unnat Krishi', respectively. Only 28.21 per cent farmers were aware about the farm magazine 'Fal Sabji'.

Thus, it can be concluded that more number of respondents were aware about the 'Khet Khaliyan' followed by 'Kheti Ri Batan' which is published from Pant Krishi Bhawan Chittorgarh, and 'Chokhi Kheti' which is published by DEE, SKRAU, Bikaner.

Further, the calculated value of chi-square (83.50) is more than the tabulated value of chi-square (13.30) at 4 degrees of freedom at 1 per cent level of significance. Which shows that there is a significant agreement between the awareness of farmers about the names of different Farm Magzines?

Hence, it can be concluded that the farmers did not differ in their awareness about the Name of different Farm Magzines. Chahal (1992), Nataraju and Perumal (1995), Sarmah and Sarmah (1996), Singh (1999) and Ghadei (2011) reported similar results. 


\section{Awareness about name of newspapers}

The data presented in the Table 4 reveal that 85.76 per cent of respondents were found aware about newspaper 'Dainik Bhaskar', followed by 'Rajasthan Patrika' (83.11 per cent), 'Dainik Jagaran' (53.31 per cent), 'Dainik Navjyoti' (58.94 per cent), respectively. Only 44.37 per cent farmers were aware about the name of 'Rajasthan Keshri', newspaper. Among the national dailes, the 'Dainik Bhaskar' was found more popular among respondents. Chahal (1992), Nataraju and Perumal (1995), Sarmah and Sarmah (1996), Singh (1999) and Ghadei (2011) reported similar results. Further, the calculated value of chi-square (181.00) is more than the tabulated value of chi-square (13.30) at 4 degrees of freedom at 1 per cent level of significance. Thus, there is a significant agreement between the awareness of farmers about the Name of different newspapers. Hence it can be concluded that the farmers did not differ in their awareness about the Name of different newspapers.

Majority of farmers were aware about the name of 'Kheti Ri Batan' programmes, aware about the timings of broadcast of the 'Kheti Ri Batan' programme and aware about, the duration of broadcast of 'Krasha ri Batan', broadcasted by AIR, Chittorgarh.

Majority of farmers were aware about the name of 'Choupal', 'Krishi Darshan', programmes, aware about the time of telecast of 'Rajasthani News', 'Choupal', 'Krishi Darshan' and were aware about the duration of telecast of 'Choupal' and 'Kheti Badi', programmes delivered from Doordharshan Kendra Chittorgarh. Majority of respondents were aware about the name of farm magazines viz. 'Khet Khaliyan', 'Kheti Ri Batan', 'Chokhi Kheti', and were aware about the name of newspapers like. 'Dainik Bhaskar' and 'Rajasthan Patrika'.

\section{References}

Annual Report. 2007. Department of Information and Public Relation Directorate of Agriculture, Rajasthan Chittorgarh.

Badodiya, S. K., Daipuria, O.P., Shakya, S.K., Guarg, S. K. and Nagayach, U.N. 2010. Perceived Effectiveness of Farm Telecast in Transfer of Agricultural Technology. Indian Research Journal of Extension Education, 10 (1): 109111.

Chahal, V.P. 1992. Comparative study of radio and TV utilization in transfer of farm technology. Ph.D. Thesis, CCS HAU, Hisar

Chauhan, N.M. 2011. Prospects and opinions of the farmers from ICT in agriculture at village level. International Journal of Extension Education, Vol. 7: 29-35.

Ghadei, K. 2011. Extension education research A review of topics selected for study. International Journal of Extension Education, Vol. 7: 71-75.

Laharia, S.N. and Joshi, N.N. 1992. Farm telecast viewing behaviour of farmers. Indian Journal of Extension Education, Vol. XXVIII No. 22: 15-22.

Narahari, N.G. 2001. Content analysis of farm broadcast programme Imphal. Indian Journal of Extension Education, Vol. XXXVII No. 3\&4: 172-178.

Nataraju, M.S. and Perumal, G. 1995. Effectiveness of farm magazine. Communicator 30 (1): 35-38.

Praveena, P.L.R.J. and Ramiah, P.V. 2007. A study on listening behaviour of farmers towards farm broadcasts of All India Radio Vijayawada, Andhra Pradesh. Indian Journal of Social Research, Vol, 48 (1) January-March: 17-25.

Sarmaha, Buduhdev and Sarmaha, Bipul 1996. Readers view in AAU farm newspaper. Ag ricultu re Extension Review, 8(4): 22-23. 
Shareef-Ud-Din. 1994. Listening behaviour and attitude of radio-owning farmers towards farm broadcasts. M.Sc. Thesis CCS HAU, Hisar.

Sharvan, R., Raja, P. and Tayeng, S. 2009. Information input pattern and information needs of tribal farmers of Arunachal Pradesh. Indian Journal of Extension Education. Vol. 45, No. 1\&2: 51-54.

Singh, J., 1999. Farmers media use profile in Hariyana. M.Sc. (Ag.) Thesis, CCS HAU, Hisar.
Slathia, P.S., Paul, N. and Nain, M.S. 2011. Awareness among farming community regarding Kissan call centres in Jammu region. International Journal of Extension Education, Vol. 7: 41-46.

Sodhi, C.S. and Sangha, G.S. 1992. Television viewing behaviour of farmers. Indian Journal of Extension Education Volume XXVIII No. 3\&4: $103-105$.

\section{How to cite this article:}

Deepa Indoria, Mani Ram and Solanki, R.L. 2018. Impact study of Influence of Agricultural Mass Media Programme on Farmers. Int.J.Curr.Microbiol.App.Sci. 7(09): 2573-2579. doi: https://doi.org/10.20546/ijcmas.2018.709.320 